\title{
STUDIES ON THE DRIFTING BEHAVIORAL PATTERNS OF MACROZOOBENTHOS IN KYUNJA GAD, A MOUNTAIN STREAM FROM GARHWAL HIMALAYA, INDIA
}

\author{
Pankaj Bahuguna ${ }^{1}$, Kumbhlesh Kamal Rana ${ }^{2}$, Rajesh Rayal ${ }^{2}$ and Hemant Kumar Joshi ${ }^{*}$

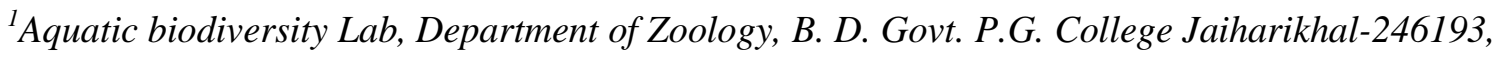 \\ Uttarakhand, India. \\ ${ }^{2}$ Department of Zoology, School of Basic and Applied Sciences, SGRR University, Patel Nagar, \\ Dehradun, Uttarakhand, India. \\ ${ }^{3}$ Department of Zoology, Government Degree College Chaubattakhal-246155, Pauri Garhwal, \\ Uttarakhand, India.
}

Corresponding Author Email id: drjoshihk2013@gmail.com

Received: 3.11.2020; Revised: 29.11.2020; Accepted: 2.12.2020

(C)Society for Himalayan Action Research and Development

\begin{abstract}
Macrozoobenthos displayed several interesting trends with regards to their occurrence and movement in the streams in response to various abiotic and biotic factors constituting the aquatic ecosystem. These are considered of great ecological significance in understanding the quality of the particular ecosystem. The present communication focused on understanding the spatial and temporal diel drifting patterns displayed by macrozoobenthos in different levels of stream orders at different duration round the clock. It was observed that there was a general preference of nocturnal and early evening hours of drifting. The drift by benthic species was performed mainly due to presence of predators, lack of proper food and breeding sites. The study revealed that highest diel drift density and diversity of macrozoobenthos was found in $3^{\text {rd }}$ order in comparison to $2^{\text {nd }}$ and $1^{\text {st }}$ order of Kyunja Gad stream. Variations were also noted in the physico-chemical parameters of streams Kyunja Gad at different orders.
\end{abstract}

Key words: Macrozoobenthos, Diel Drifting Pattern, Kyunja Gad Mountain stream, Garhwal Himalaya, India

\section{Introduction}

Muller (1954) was the pioneer in describing downward transport of benthic invertebrates as drift. It is considered as common phenomenon in running water bodies (Brittian and Eikeland, 1988). Drift is considered to be an important feature of lotic ecosystem as it promotes dispersal and colonization of aquatic organisms (Towsend, 1989; Hughes, 1998).The drift is classified as catastrophic, behavioral, active, distributional and constant (Brittain and Eikeland, 1988). Invertebrate drift is thus defined as the downstream movement of benthic invertebrates in the water column that is generally found in or around the substratum of streams and rivers (Anderwald et al., 1991).
Earlier work on diel periodicity was conducted by Moon (1940) and Harker (1953). Studies on diel drift however, showed a notable trend after 1960, stimulated by the discovery of diel periodicity in many taxa in several parts of the world (Water 1972; Muller 1974). Two mechanisms are recognized for diel periodicity on the substratum namely (a). Diel positioning change and (b) Diel activity levels (Wiley and Kohler, 1984). Diel positioning changes of macrozoobenthos mainly referred to diel density changes in the top surface of the substratum. The reasons mainly accounted for various theories proposed for this mechanism regarding presence of those benthic animals on the top surfaces of the substratum mainly at night being Phototaxis, response to predation, foraging 
periodicity, and respiratory needs of animals (Hynes 1970; Waters 1972; Wiley and Kohler 1984).

In Garhwal region, the studies on benthic macroinvertebrates dynamics have been carried out by several researchers (Dobriyal et al., 2009; Katoch et.al.,2015; Balodi and Koshal (2015;, Koshal et al. (2017); Bahuguna et.al., 2019; ), but drift studies are almost neglected. Majority of drifting studies till date have been conducted at relatively lower altitude and no published literature was found on the diel drifting behavioral patterns of the Indian central Himalayan water system flowing in different order levels. Therefore, the present study was undertaken to fill this lacuna in literature.

\section{Material and Methods}

\section{Study area}

The study was conducted in Kyunja Gad stream a spring fed perennial tributary of Mandakini river from Garhwal Himalaya, India. It originates from Swami Kartik temple at an elevation of 1497 meter. Stream is narrow in upper course, widening towards its confluence with river Mandakini. Substratum of stream consists of boulders, cobbles, pebbles and tiny sand particles. Habitat heterogeneity (riffle, run, rapid, and pool) is a characteristic feature of the stream. Sampling sites were selected for Kyunja Gad stream in first order (origin of stream), second order (confluence of two first order streams create a $2^{\text {nd }}$ order stream) and third order (confluence of two second order streams forms a $3^{\text {rd }}$ order stream). Three sampling Sites: $1^{\text {st }}$ order stream (Spot $\mathrm{K}_{1}-30^{\circ} 21.11^{\prime} \mathrm{N}$ and $78^{\circ} 58.40^{\prime}$ E) near Monkhal village, $2^{\text {nd }}$ order stream (Spot $\mathrm{K}_{2}-30^{\circ} 25^{\prime} 20^{\prime \prime} \mathrm{N}$ and $79^{\circ}$ 07’38”E) Jayakandi village and $3^{\text {rd }}$ order stream (Spot $\mathrm{K}_{3}$ $30^{\circ} 25^{\prime} 08^{\prime \prime} \mathrm{N}$ and $79^{\circ} 03^{\prime} 52^{\prime \prime} \mathrm{E}$ ) were studied at Chandrapuri market near the confluence of the stream with the river Mandakani (Fig.1).

\section{Sampling Method}

The drifting sampling method was followed as per Smock (1996). The drift nets described by FieldDodgson (1965) having an internal diameter of $16.6 \mathrm{~cm}$, a length of $1.7 \mathrm{~m}$ and 220 micron mesh size has been used. The nets were set for 3hours. As far as possible replicate samples were taken for riffle and runs for increased precision in estimates of total density and species diversity.

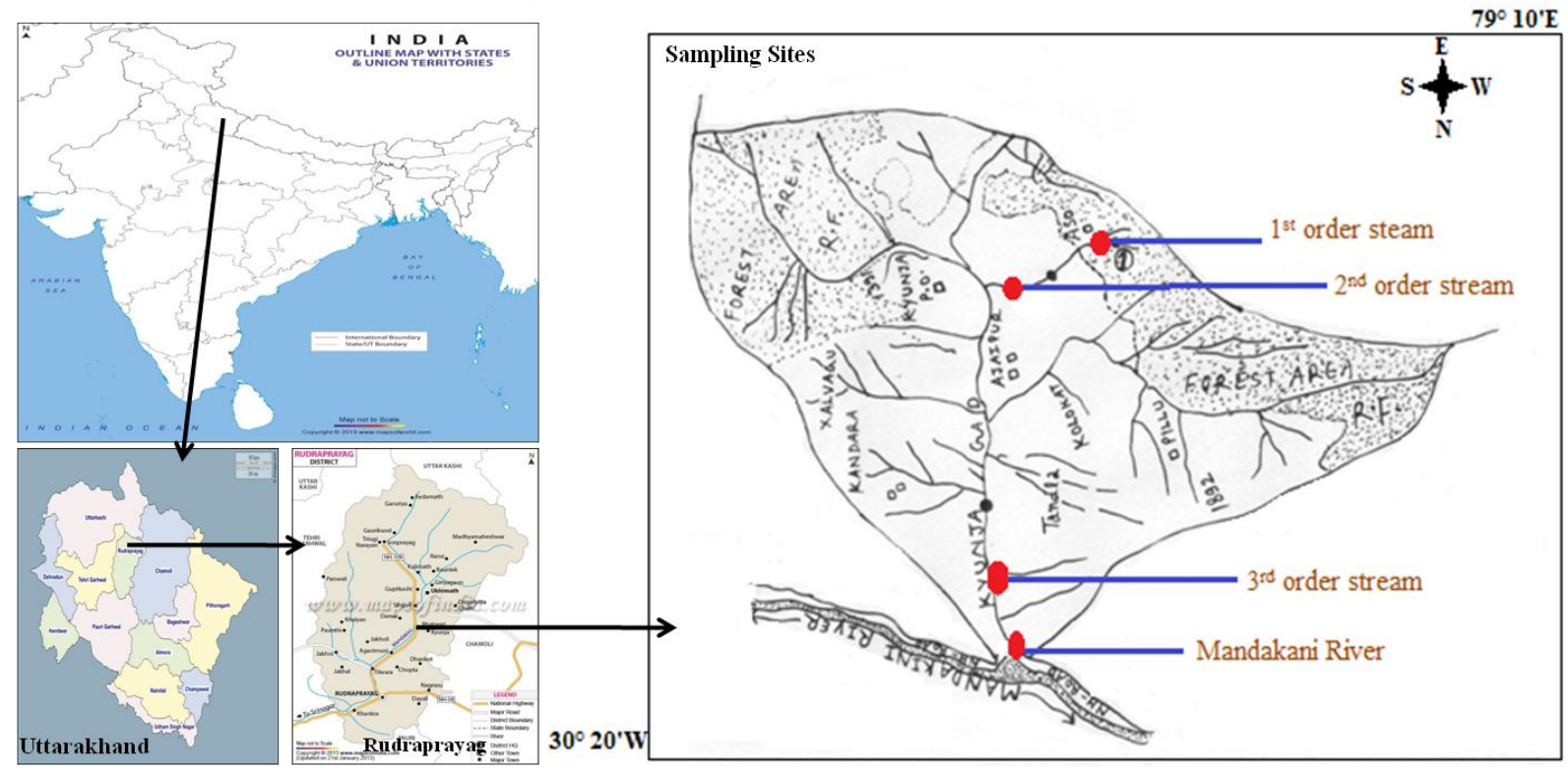

Figure 1: Sampling sites in Kyunja Gad.

The diel drift density of various macrozoobenthos was collected during different periods of the whole day at all the 3 spots $\left(1^{\text {st }}\right.$ order, $2^{\text {nd }}$ order and $3^{\text {rd }}$ order stream) and population has been expressed in individuals $/ 100 \mathrm{~m}^{3} /$ hours. 
The drifting macrozoobenthos were preserved in $70 \%$ ethyl alcohol and brought to the laboratory for enumeration and identification using standard keys and monographs (Ward and Whipple, 1966; Needham and Needham, 1962; Tomka and Zurwerra, 1985 etc.). The identification was done to the lowest possible taxon. APHA (1976) protocols were used for the measurement of Physico-chemical conditions prevailing at $1^{\text {st }}, 2^{\text {nd }}$ and $3^{\text {rd }}$ order streams during each collection period.

\section{Results}

Characteristics of Abiotic factors in Kyunja Gad Stream: Variations were noted in the physico-chemical parameters of different order streams of Kyunja Gad. Water temperature of the stream oscillated from $7.9 \pm 1.1^{\circ} \mathrm{C}$ to $15.8 \pm 1.2^{\circ} \mathrm{C}$ ( $1^{\text {st }}$ Order Stream $), 10.9 \pm 2.1^{\circ} \mathrm{C}$ to $22.2 \pm 2.4^{0} \mathrm{C}\left(2^{\text {nd }}\right.$ Order stream) and $15.8 \pm 2.7^{\circ} \mathrm{C}$ to $23.5 \pm 3.1^{\circ} \mathrm{C}\left(3^{\text {rd }}\right.$ O.S.). Similarly, current velocity ranged from $0.256 \pm 0.021 \mathrm{~m} . \mathrm{s}^{-1}$ to $0.656 \pm 0.032 \mathrm{~m} . \mathrm{s}^{-1}\left(1^{\text {st }}\right.$ O.S. $)$,
$0.264 \pm 0.035 \mathrm{~m} . \mathrm{s}^{-1} \quad$ to $\quad 0.728 \pm 0.097 \mathrm{~m} \cdot \mathrm{s}^{-1}\left(2^{\text {nd }} \mathrm{O} . S\right.$. $)$ and $0.340 \pm 0.051$ to $0.875 \pm 0.754 \mathrm{~m} . \mathrm{s}^{-1}$ (3rd O.S.). Dissolved oxygen content varied from $7.4 \pm 0.2$ to $9.4 \pm 1.6 \mathrm{mg} .1^{-1}\left(1^{\mathrm{st}}\right.$ O.S.), $7.2 \pm 0.2$ to $9.1 \pm 0.7 \mathrm{mg} . \mathrm{l}^{-1}$ $\left(2^{\text {nd }}\right.$ O.S. $)$ and $7.0 \pm 0.2$ to $8.9 \pm 0.5$ mg..$^{-1}\left(3^{\text {rd }}\right.$ O.S. $)$.

\section{Diel drifting variation of macrozoobenthos in different order streams}

A total of 2202 samples were collected throughout the study period collectively from all the three sites. Among all the three sites maximum specimens were obtained from $3^{\text {rd }}$ order stream (1160 samples) followed by $2^{\text {nd }}$ order stream (791 samples) whereas least from $1^{\text {st }}$ order stream (323samples). Along with the number of specimens collected, the species richness and species belonging to different orders of aquatic insect followed the similar trend with maximum being 40 species belonging to 9 orders, 32 species belonging to 8 orders and 17 species belonging to 6 insect orders respectively in $3^{\text {rd }}, 2$ nd and 1 st order Kyunja stream (Fig.2).

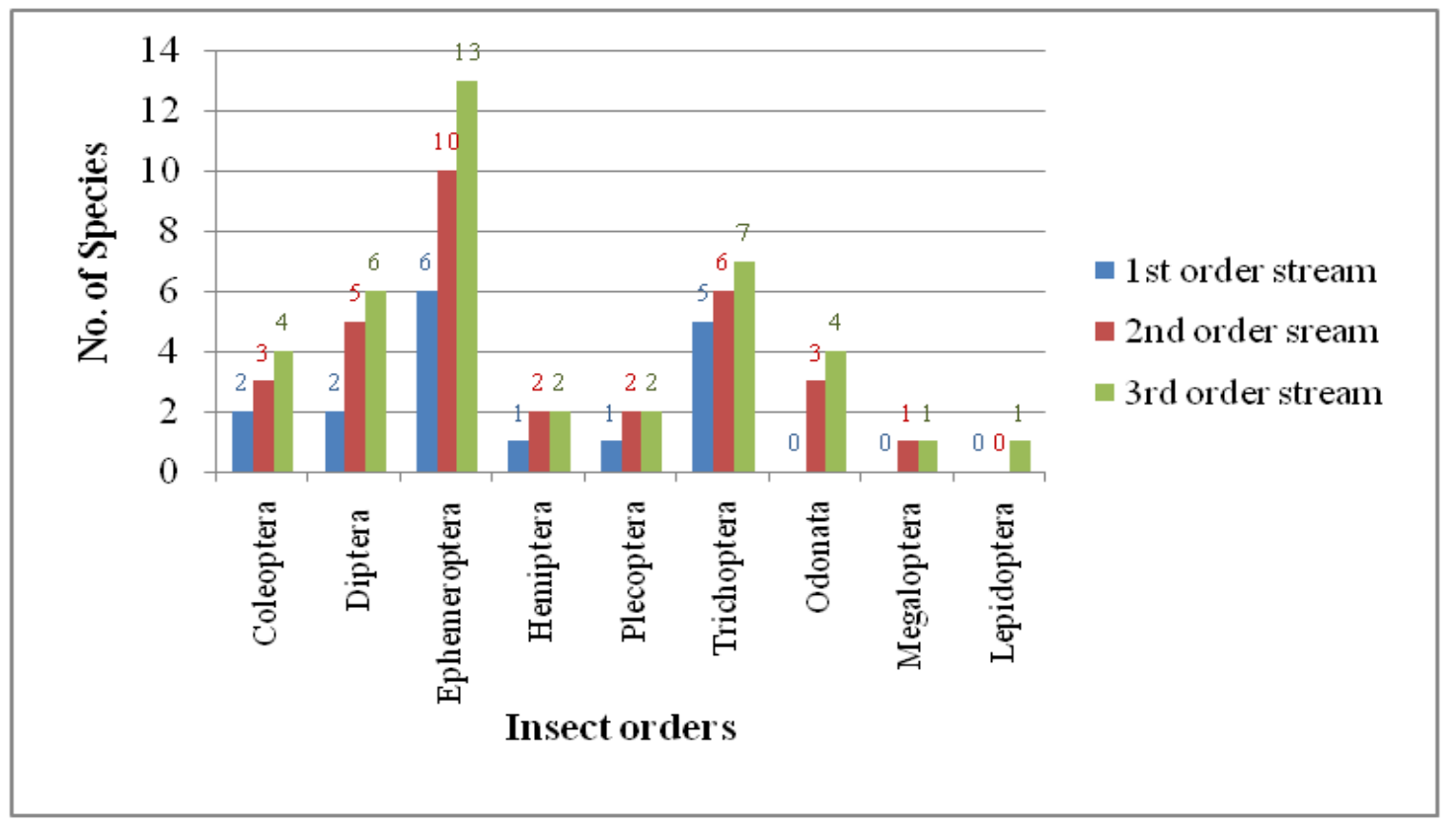

Figure 2: Graph showing different orders with number of species found in all three streams Diel drifting behavioral patterns in different order streams

order. During the study fifteen (15) common

The study reveals that maximum diel drift density and diversity of macrozoobenthos was found in $3 \mathrm{rd}$ order stream in comparison to $2 \mathrm{nd}$ and $1 \mathrm{st}$ species were recorded from all the sampling sites

they are Psephenus tenulpes, Elmid (larva), Simulium, Tipula, Caenis, Ecdyonurus, 
Ephemerella indica, Heptagenia, Heleocoris vicinus, Neoperla, Hydropsyche, Stenopsyche himalayana, Chimarra, Glossosoma caudatum and Rhyacophila similis.

Sixteen (16) species were found common in 2 nd and 3rd order stream namely Hydrophilus, Atherix, Antocha, Chironomus, Ameletus, Atalophlebie, Baetis rhodani, Prosopistoma, Crinitella, Rhithrogeniella, Gerris, Argia, Zygonyx, Euphaea, Stenopsyche himvatika and Corydalus camutus. Isonychia is the one only found in both 1st and 3rd order stream. Eight (8) species viz. Berosus indicus, Hemerodromia, Platybaetis, Siphhlonurus, Progomphus, Isoperla, Chematopsycle, and Parapoynx found only from 3rd order stream. Throughout the study a total number of 42 species were observed from 9 different orders.

In case of 1 st order stream, it was noticed that Simulium, Psephenus tenulpes, Baetis niger and Hydropsyche was found maximum in number with total of 42, 37, 31 and 30 respectively (Table 1). In case of 2 nd order stream it was noticed that Baetis rhodani (105), Ameletus (51), Psephenus tenulpes (46), Caenis (46), Hydropsyche (36) and Heptagenia (36) recorded maximum in number with total of 791 samples (Table 2). In case of $3^{\text {rd }}$ order stream, it was observed that Berosus indicus (21), Psephenus tenulpes (81), Simulium (109), Ameletus (131), Baetis rhodani (87), Caenis (52), Ecdyonurus (95), Euphaea (24), Neoperla (32), Hydropsyche (48), Stenopsyche himvatika (44), Stenopsyche himalayana (27), Chimarra (39), Parapoynx (40) was found highest in total number during the whole diel drifting sampling work round the year (Table 3 ).

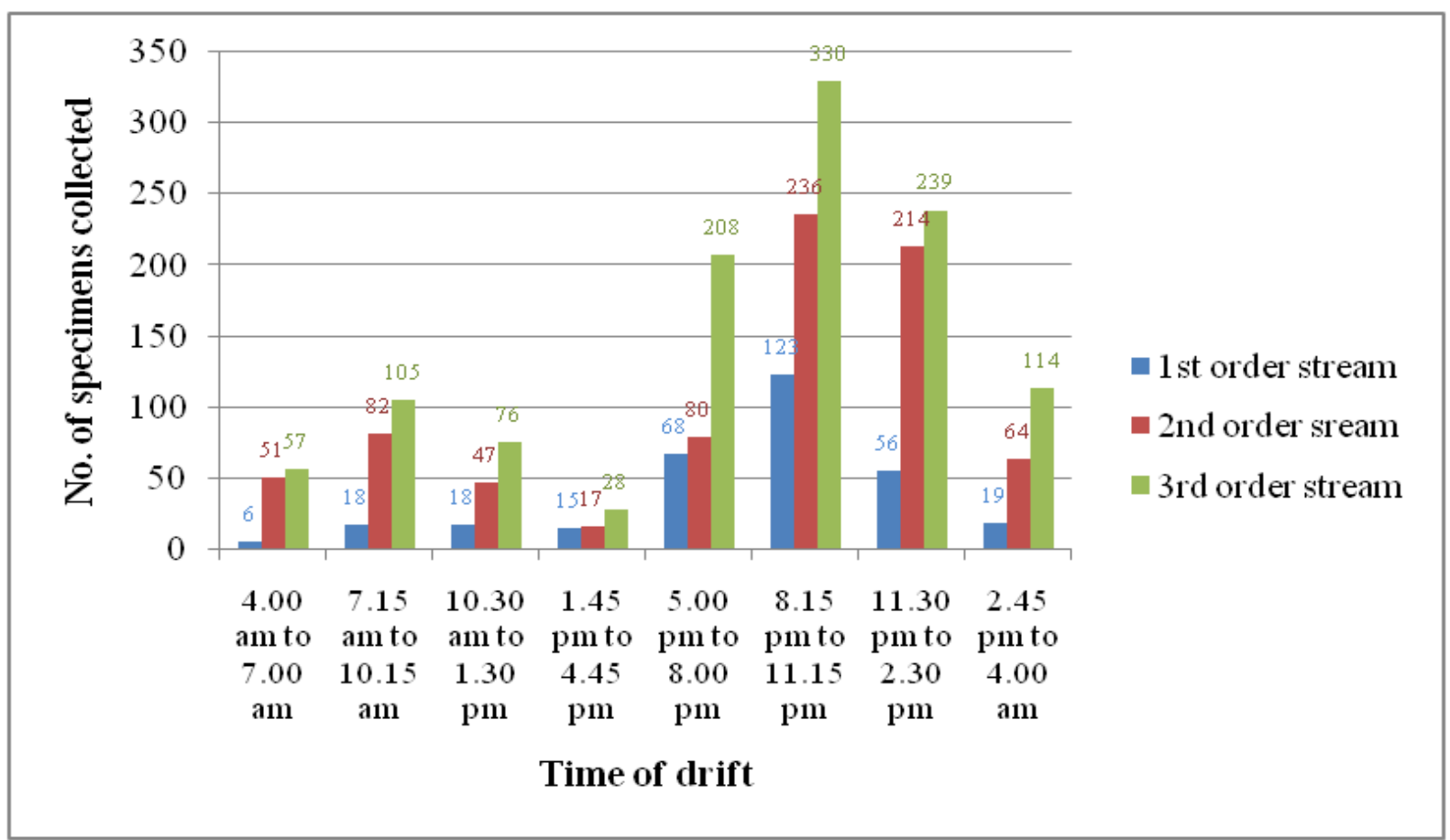

Figure 3: Graph showing diel drift of macrozoobenthos in all three streams. 
J. Mountain Res. P-ISSN: 0974-3030, E-ISSN: 2582-5011

Table 1: Diel drift value of macrozoobenthos observed in $1^{\text {st }}$ order stream Kyunja Gad during October 2017 to September 2018

\begin{tabular}{|c|c|c|c|c|c|c|c|c|c|c|}
\hline \multirow[t]{2}{*}{$\mathbf{S . N}$} & \multirow{2}{*}{$\begin{array}{c}\text { Periodicity } \\
\text { Sampling Time }\end{array}$} & \multicolumn{4}{|c|}{ Diurnal drift } & \multicolumn{4}{|c|}{ Nocturnal drift } & \multirow{3}{*}{$\begin{array}{l}\text { Total } \\
\text { no. } \\
\text { of diel } \\
\text { drift } \\
\text { indivi-dual }\end{array}$} \\
\hline & & $\begin{array}{l}\text { 4.00am } \\
\text { to } \\
7.00 \mathrm{am}\end{array}$ & $\begin{array}{l}\begin{array}{l}7.15 \mathrm{am} \\
\text { to } \\
10.15 \mathrm{am}\end{array}\end{array}$ & $\begin{array}{l}\begin{array}{l}10.30 \mathrm{am} \\
\text { to } \\
1.30 \mathrm{pm}\end{array} \\
\text {. }\end{array}$ & $\begin{array}{l}1.45 \mathrm{pm} \\
\text { to } \\
4.45 \mathrm{pm}\end{array}$ & $\begin{array}{l}5.00 \mathrm{pm} \\
\text { to } \\
8.00 \mathrm{pm}\end{array}$ & $\begin{array}{l}8.15 \mathrm{pm} \\
\text { to } \\
11.15 \mathrm{pm}\end{array}$ & $\begin{array}{l}\begin{array}{l}11.30 \mathrm{pm} \\
\text { to } \\
2.30 \mathrm{am}\end{array}\end{array}$ & $\begin{array}{l}2.45 \mathrm{am} \\
\text { to } \\
4.00 \mathrm{am}\end{array}$ & \\
\hline Order & $\begin{array}{c}\text { Name of the Genus/ } \\
\text { species }\end{array}$ & $\begin{array}{c}\text { Early } \\
\text { morning }\end{array}$ & $\begin{array}{c}\text { Late } \\
\text { morning }\end{array}$ & $\begin{array}{c}\text { Day } \\
\text { Period }\end{array}$ & Day Period & $\begin{array}{r}\text { Early } \\
\text { evening }\end{array}$ & $\begin{array}{l}\text { Night } \\
\text { period }\end{array}$ & $\begin{array}{l}\text { Night } \\
\text { period }\end{array}$ & $\begin{array}{l}\text { Night } \\
\text { period }\end{array}$ & \\
\hline \multicolumn{11}{|c|}{ Coleoptera } \\
\hline 1 & Psephenus tenulpes & 0 & 0 & 0 & 0 & 10 & 19 & 5 & 3 & 37 \\
\hline 2 & Elmid(larva) & 0 & 0 & 0 & 0 & 0 & 9 & 5 & 0 & 14 \\
\hline \multicolumn{11}{|l|}{ Diptera } \\
\hline 3 & Simulium & 0 & 0 & 0 & 0 & 7 & 21 & 9 & 5 & 42 \\
\hline 4 & Tipula & 1 & 2 & 6 & 5 & 2 & 4 & 1 & 1 & 22 \\
\hline \multicolumn{11}{|c|}{ Ephemeroptera } \\
\hline 5 & Baetis niger & 0 & 0 & 0 & 0 & 8 & 14 & 6 & 3 & 31 \\
\hline 6 & Caenis & 0 & 0 & 0 & 0 & 7 & 9 & 2 & 0 & 18 \\
\hline 7 & Ecdyonurus & 0 & 0 & 0 & 0 & 3 & 3 & 5 & 1 & 12 \\
\hline 8 & Ephemerella indica & 1 & 2 & 1 & 1 & 1 & 1 & 2 & 1 & 10 \\
\hline 9 & Heptagenia & 0 & 0 & 0 & 0 & 7 & 8 & 5 & 2 & 22 \\
\hline 10 & Isonychia & 1 & 5 & 6 & 2 & 0 & 0 & 0 & 0 & 14 \\
\hline \multicolumn{11}{|l|}{ Hemiptera } \\
\hline 11 & Heleocoris vicinus & 1 & 2 & 2 & 2 & 3 & 2 & 2 & 1 & 15 \\
\hline \multicolumn{11}{|l|}{ Plecoptera } \\
\hline 12 & Neoperla & 0 & 2 & 1 & 1 & 0 & 2 & 2 & 0 & 08 \\
\hline \multicolumn{11}{|l|}{ Trichoptera } \\
\hline 13 & Hydropsyche & 0 & 0 & 0 & 0 & 8 & 17 & 5 & 0 & 30 \\
\hline 14 & Stenopsyche himalayana & 1 & 3 & 2 & 2 & 0 & 3 & 2 & 1 & 14 \\
\hline 15 & Chimarra & 0 & 0 & 0 & 0 & 6 & 7 & 3 & 1 & 17 \\
\hline 16 & Glossosoma caudatum & 0 & 0 & 0 & 0 & 5 & 3 & 1 & 0 & 09 \\
\hline 17 & Rhyacophila similis & 1 & 2 & 0 & 2 & 1 & 1 & 1 & 0 & 08 \\
\hline \multicolumn{2}{|r|}{ Total } & 6 & 8 & 18 & 15 & 68 & 123 & 56 & 119 & 323 \\
\hline
\end{tabular}


J. Mountain Res. P-ISSN: 0974-3030, E-ISSN: 2582-5011
Vol. 15, (2020), 97-108
DOI: https://doi.org/10.51220/jmr.v15il.11

Table 2: Diel drift value of macrozoobenthos observed in $2^{\text {nd }}$ order stream Kyunja Gad during October 2017 to September 2018

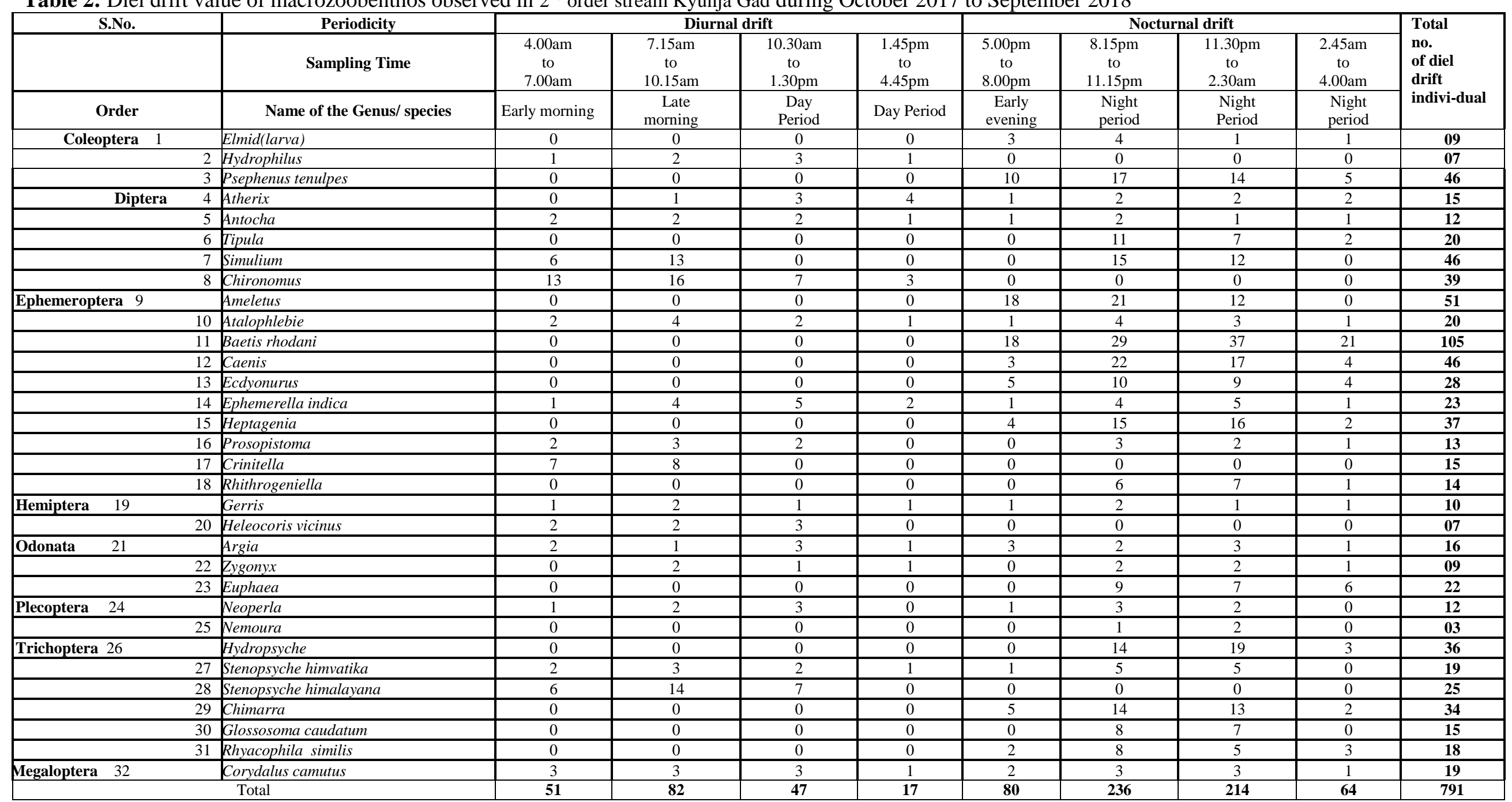


J. Mountain Res. P-ISSN: 0974-3030, E-ISSN: 2582-5011

Table 3: Diel drift value of macrozoobenthos observed in $3^{\text {rd }}$ order stream Kyunja Gad during October 2017 to September 2018

\begin{tabular}{|c|c|c|c|c|c|c|c|c|c|c|}
\hline \multirow[t]{2}{*}{ S.No. } & \multirow{2}{*}{$\begin{array}{c}\text { Periodicity } \\
\text { Sampling Time }\end{array}$} & \multicolumn{4}{|c|}{ Diurnal drift } & \multicolumn{4}{|c|}{ Nocturnal drift } & \multirow{3}{*}{$\begin{array}{r}\text { Total } \\
\text { no } \\
\text { of die } \\
\text { drif } \\
\text { indivi } \\
\text { dua }\end{array}$} \\
\hline & & $\begin{array}{c}\text { 4.00am } \\
\text { to } \\
7.00 \mathrm{am}\end{array}$ & $\begin{array}{c}\begin{array}{c}7.15 \mathrm{am} \\
\text { to } \\
10.15 \mathrm{am}\end{array} \\
\end{array}$ & $\begin{array}{c}\begin{array}{c}10.30 \mathrm{am} \\
\text { to } \\
1.30 \mathrm{pm}\end{array} \\
\end{array}$ & $\begin{array}{c}1.45 \mathrm{pm} \\
\text { to } \\
4.45 \mathrm{pm}\end{array}$ & $\begin{array}{l}5.00 \mathrm{pm} \\
\text { to } \\
8.00 \mathrm{pm}\end{array}$ & $\begin{array}{l}8.15 \mathrm{pm} \\
\text { to } \\
11.15 \mathrm{pm}\end{array}$ & $\begin{array}{c}11.30 \mathrm{pm} \\
\text { to } \\
2.30 \mathrm{am}\end{array}$ & $\begin{array}{c}2.45 \mathrm{am} \\
\text { to } \\
4.00 \mathrm{am}\end{array}$ & \\
\hline Order & Name of the Genus/ species & $\begin{array}{c}\text { Early } \\
\text { morning }\end{array}$ & $\begin{array}{c}\text { Late } \\
\text { morning }\end{array}$ & $\begin{array}{c}\text { Day } \\
\text { Period }\end{array}$ & $\begin{array}{c}\text { Day } \\
\text { Period } \\
\end{array}$ & $\begin{array}{l}\text { Early } \\
\text { evening }\end{array}$ & $\begin{array}{l}\text { Night } \\
\text { period }\end{array}$ & $\begin{array}{l}\text { Night } \\
\text { period }\end{array}$ & $\begin{array}{l}\text { Night } \\
\text { period }\end{array}$ & \\
\hline Coleoptera & Berosus indicus & 3 & 2 & 4 & 2 & 2 & 5 & 1 & 2 & 21 \\
\hline 2 & Elmid(larva) & 0 & 0 & 0 & 0 & 3 & 5 & 1 & 1 & 10 \\
\hline 3 & Hydrophilus & 2 & 4 & 4 & 0 & 0 & 0 & 0 & 0 & 10 \\
\hline 4 & Psephenus tenulpes & 0 & 0 & 0 & 0 & 16 & 31 & 25 & 9 & 81 \\
\hline Diptera & Atherix & 0 & 2 & 3 & 0 & 1 & 3 & 2 & 2 & 13 \\
\hline 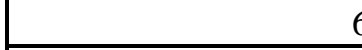 & Antocha & 1 & 0 & 2 & 1 & 1 & 2 & 1 & 1 & 09 \\
\hline 7 & Tipula & 0 & 0 & 0 & 0 & 2 & 6 & 8 & 2 & 18 \\
\hline$\varepsilon$ & Simulium & 10 & 24 & 18 & 8 & 9 & 14 & 17 & 9 & 109 \\
\hline S & Chironomus & 5 & 8 & 6 & 0 & 0 & 0 & 0 & 0 & 19 \\
\hline 10 & Hemerodromia & 0 & 0 & 0 & 0 & 1 & 5 & 3 & 0 & 09 \\
\hline Ephemeroptera 11 & Ameletus & 0 & 0 & 0 & 0 & 32 & 41 & 38 & 20 & 131 \\
\hline 12 & Atalophlebie & 2 & 3 & 2 & 2 & 3 & 4 & 2 & 1 & 19 \\
\hline 13 & Baetis rhodani & 0 & 0 & 0 & 0 & 11 & 33 & 24 & 19 & 87 \\
\hline 14 & Caenis & 0 & 0 & 0 & 0 & 19 & 14 & 16 & 3 & 52 \\
\hline 15 & Ecdyonurus & 0 & 0 & 0 & 0 & 23 & 35 & 24 & 13 & 95 \\
\hline 16 & Ephemerella indica & 3 & 4 & 2 & 2 & 2 & 3 & 2 & 1 & 19 \\
\hline 17 & Heptagenia & 0 & 0 & 0 & 0 & 3 & 7 & 5 & 2 & 17 \\
\hline 18 & Prosopistoma & 1 & 3 & 1 & 1 & 2 & 2 & 1 & 1 & 12 \\
\hline 19 & Isonychia & 3 & 5 & 3 & 0 & 0 & 0 & 0 & 0 & 11 \\
\hline 20 & Platybaetis & 2 & 5 & 0 & 0 & 0 & 0 & 0 & 0 & 07 \\
\hline 21 & Crinitella & 2 & 4 & 0 & 0 & 0 & 0 & 0 & 0 & 06 \\
\hline 22 & Rhithrogeniella & 0 & 0 & 0 & 0 & 5 & 4 & 1 & 1 & 11 \\
\hline 23 & Siphhlonurus & 5 & 7 & 0 & 0 & 0 & 0 & 0 & 0 & 12 \\
\hline
\end{tabular}


J. Mountain Res. P-ISSN: 0974-3030, E-ISSN: 2582-5011

\begin{tabular}{|c|c|c|c|c|c|c|c|c|c|c|}
\hline Hemiptera 24 & Gerris & 2 & 1 & 3 & 1 & 1 & 3 & 1 & 1 & 13 \\
\hline 25 & Heleocoris vicinus & 1 & 4 & 3 & 0 & 0 & 0 & 0 & 0 & 08 \\
\hline Odonata & Argia & 1 & 2 & 1 & 1 & 1 & 2 & 1 & 0 & 09 \\
\hline 27 & Zygonyx & 1 & 1 & 1 & 1 & 1 & 1 & 1 & 1 & 08 \\
\hline 28 & Euphaea & 0 & 0 & 0 & 0 & 7 & 10 & 4 & 3 & 24 \\
\hline 29 & Progomphus & 0 & 0 & 0 & 0 & 2 & 3 & 2 & 0 & 07 \\
\hline $\begin{array}{ll}\text { Plecoptera } & 30\end{array}$ & Neoperla & 3 & 5 & 5 & 3 & 4 & 6 & 4 & 2 & 32 \\
\hline 31 & Isoperla & 0 & 0 & 0 & 0 & 3 & 3 & 7 & 1 & 14 \\
\hline Trichoptera 32 & Hydropsyche & 0 & 0 & 0 & 0 & 15 & 22 & 10 & 1 & 48 \\
\hline 33 & Stenopsyche himvatika & 3 & 8 & 7 & 4 & 5 & 7 & 8 & 2 & 44 \\
\hline 34 & Stenopsyche himalayana & 6 & 11 & 9 & 1 & 0 & 0 & 0 & 0 & 27 \\
\hline 35 & Chimarra & 0 & 0 & 0 & 0 & 10 & 19 & 8 & 2 & 39 \\
\hline 36 & Glossosoma caudatum & 0 & 0 & 0 & 0 & 6 & 7 & 7 & 4 & 20 \\
\hline 37 & Rhyacophila similis & 0 & 0 & 0 & 0 & 4 & 9 & 3 & 1 & 18 \\
\hline 38 & Chematopsycle & 1 & 2 & 2 & 1 & 1 & 2 & 1 & 0 & $\mathbf{1 0}$ \\
\hline Megaloptera 39 & Corydalus camutus & 0 & 0 & 0 & 0 & 6 & 8 & 2 & 2 & 18 \\
\hline Lepidoptera 40 & Parapoynx & 0 & 0 & 0 & 0 & 8 & 15 & 11 & 6 & 40 \\
\hline Total & & 57 & 105 & 76 & 28 & 209 & 331 & 241 & 113 & 1157 \\
\hline
\end{tabular}


Maximum drift was noticed during the night phase in all the streams while minimum was seen in day time. In $1^{\text {st }}$ order stream 10 out of total 17 species exhibited nocturnal drift i $(5.00 \mathrm{pm}$ to $8.00 \mathrm{pm}$ and $8: 15 \mathrm{pm}$ to $11: 15 \mathrm{pm}$ ) while only one species Isonychia drifted in a incessant pattern throughout day time. Rest species Tipula, Ephemerella indica, Heleocoris vicinus, Neoperla, Stenopsyche himalayana and Rhyacophila similis followed irregular patterns throughout the 24 hours with no special affinity for any specific day or night hours. (Table 1). The maximum drift (123 individuals $/ 100 \mathrm{~m}^{3} / 3$ hours) was observed in night period around $5.0 \mathrm{pm}$ to $8.0 \mathrm{pm}$ and $8: 15 \mathrm{pm}$ to $11: 15 \mathrm{pm}$ and in $1^{\text {st }}$ order stream. Minimum (06 individuals $/ 100 \mathrm{~m}^{3} / 3$ hours) were recorded during early morning hours around 4:0am to 7:0am. In case $2^{\text {nd }}$ order stream, lowest drift number (17individuals $/ 100 \mathrm{~m}^{3} / 3$ hours) was recorded during day time between $1: 45 \mathrm{pm}$ to $4: 45 \mathrm{pm}$ (Table 2 and Fig.3) and highest drift number (236 and 214individuals $/ 100 \mathrm{~m}^{3} / 3$ hours) in night period (8:15pm to $11: 15 \mathrm{pm}$ and $11.30 \mathrm{pm}$ to $2.30 \mathrm{am}$ ). In the 2 nd order stream 15 out of total 32 species exhibited continuous night drift and 12 species had irregular pattern of drift (Table 2). There were five species Hydrophilus, Chironomus, Crinitella, Heleocoris vicinus and Stenopsyche himalayana which were seen following a continuous pattern of diurnal drift indicating that they are found only at day time.

During investigation of $3^{\text {rd }}$ order stream, it was observed that 19 species out 40 showed array of continuous nocturnal drift and 13 species displayed discontinuous pattern of movement during both day and night time. Concurrently only 8 species Hydrophilus, Chironomus, Isonychia, Platybaetis, Crinitella, Siphhlonurus, Heleocoris vicinus and Stenopsyche himalayana demonstrated continuous diurnal drift pattern (Table 3). Minimum drift number (28individuals $/ 100 \mathrm{~m}^{3} / 3$ hours) was recorded during day period between $1: 45 \mathrm{pm}$ to $4: 45 \mathrm{pm}$ (Table 3 and Fig.3) and peak drift number (331 and 214 individuals $/ 100 \mathrm{~m}^{3} / 3$ hours) was noticed in night period of $8: 15 \mathrm{pm}$ to $11: 15 \mathrm{pm}$ and $11.30 \mathrm{pm}$ to $2.30 \mathrm{pm}$ at this spot.

\section{Discussion}

Significant drift pattern of macrozoobenthos was recorded in the present study which varied in different levels of stream order due to their geomorphological characteristics. In the first order stream only 10 species were observed performing diel drift (order-Coleoptera-Psephenus tenulpes and Elmid(larva);order-Diptera-Simulium; orderEphemeroptera-Baetis niger, Caenis, Ecdyonurus and Heptagenia; order-Trichoptera-Hydropsyche, Chimarra, Glossosoma caudatum) while the number increased to 15 in second order (orderColeoptera-Elmid (larva) and Psephenus tenulpes; order-Diptera-Tipula; order-EphemeropteraAmeletus, Baetis rhodani, Caenis, Ecdyonurus, Heptagenia and Rhithrogeniella; order-OdonataEuphaea, Nemoura, order-TrichopteraHydropsyche, Chimarra, Glossosoma caudatum and Rhyacophila similis) and 19 in $3^{\text {rd }}$ order (order- Coleoptera- Elmid (larva) and Psephenus tenulpes; order-Diptera-Tipula and Hemerodromia; order-Ephemeroptera-Ameletus, Baetis rhodani, Caenis, Ecdyonurus, Heptagenia sulphurea and Rhithrogeniella; order-OdonataEuphaea and Progomphus; order-PlecopteraIsoperla; order-Trichoptera-Hydropsyche, Chimarra, Glossosoma caudatum and Rhyacophila similis; order- MegalopteraCorydalus camutus and order-LepidopteraParapoynx).

Similar observations were reported by Moon (1940); Elliott (1968) and Bailey (1981). Casey (1987) reported that a diel periodicity for Drunella coloradensis and Baetis nymphs was found at proportionally greater densities on the top of the substratum in the dark than in the light period.

Elliott (2002) reported that the mechanism of invertebrate drift often leads to an increase in upstream movements and in downstream dispersal. Most streams invertebrate increase their activity at night. It is generally observed that the highest density occurs just after sunset and another one (slightly lower) before sunrise (Waters 1972; Brittain and Eikeland 1988; Allan 1995). High nocturnal densities of prey on top of 
the substratum is chiefly escape from the a visually feeding predator active during day hours moreover, nocturnal decrease in dissolved oxygen in the substratum may cause a migration from the bottom surfaces of the substratum to more exposed surfaces at night (Wiley and Kohler 1980).

Some benthic insects were also observed performing daylight drifts in Kyunja Gad Stream. One species (Isonychia) in first order stream, five (Hydrophilus, Chironomus, Crinitella, Heleocoris vicinus and Stenopsyche himalayana) in second order stream and eight species (Hydrophilus, Chironomus, Isonychia, Platybaetis, Crinitella, Siphhlonurus, Heleocoris vicinus and Stenopsyche himalayana) in third order stream were observed performing specific day light drift. Several studies that employed direct observations on running water streams macrozoobenthos have demonstrated density increases in the day light (Graesser and Lake 1984; Statzner and Mogel 1984, 1985; Allan et.al. 1986).

The species like Tipula, Ephemerella indica, Heleocoris vicinus, Neoperla, Stenopsyche himalayana Rhyacophila similis, Atherix, Antocha, Simulium, Atalophlebie, Prosopistoma, Gerris, Argia, Zygonyx, Neoperla, Stenopsyche himvatika, Corydalus camutus, Berosus indicus and Chematopsyche showed indefinite pattern of drift in all the 3 sites studied. Irregular drift pattern is reported by many limnologists working on macro zoobenthos. Incident light has been shown to be key role in the management of drift behavioral patterns. (Water 1972; Muller 1974; Casey 1987).

Day-night alterations in the spatial distribution of insects in a stony stream were studied by Elliott (2002). The nocturnal activities of mayfly Baetis was interpreted by Kohler (1985) mainly through the foraging activities which was however opposed by Wilzbach (1990). When animals are abundant enough to outbalance the capacity of their microhabitat, density-dependent drift is observed. However, population densities are maintained below this level due to physical perturbation and predation (Bishop and Hynes 1969; Ciborowski 1983). Hay et al. (2008) reported the influence of limited food availability on the drifting behaviour of Macrozoobenthos. Statzner et.al, (1985) noted that abundance of food, predators and intra-specific density are the most important biotic factors affecting the drift of a taxon. Fish predation and invertebrate drift (odonata) relation was also reported by Bahuguna et al. (2019).

\section{Conclusion}

The study emphasizes on the fact that drift is a very important behavior of benthic insects at larval and nymphal stage which is performed specifically by different species during either night hours or day light hours or may be irregular depending upon eco-physiological requirements.

\section{Acknowledgements}

Author (P.B.) gratefully acknowledges the financial assistance rendered by Science and Engineering Research Board (SERB) as a major Project F. No. -ECR/2016/001291. Authors are indebted to Prof. A. K. Dobriyal, Head of Zoology Department, Campus Pauri, H. N .B. Garhwal University (A Central University) Pauri Garhwal for constant encouragement.

\section{References}

Allan JD (1995) Stream ecology. Structure and function of running waters. Chapman \& Hall London: 1-388.

Allan JD Flecker AS and McClintock NL (1986) Diel epibenthic activity of mayfly nymphs and it nonconcordance with behavioural drift. Limnol. Oceanogr.31: 1057-1065.

Anderwald PH, Konar HM and Humpesch UH (1991) Continuous drift samples of macroinvertebrates in a large river, the Danube in Austria. Freshw. Biol. 25: 461476.

APHA (1976) Standard methods for the examination of water and waste waters. APHA, AWWA and WPCF, New York. 1-1193. 
Bahuguna P, Joshi HK and Kumar K (2019) A report on drifting behaviour of odonata (aquatic insects) in Kyunja Gad, a spring fed tributary of river Mandakani, Chamoli Garhwal, Uttarakhand. J. Mountain Res. 14(2): 63-67.

Bailey PCE (1981). Diel activity patterns in nymphs of an Australian mayfly

Atalophlebioides sp. (Ephemeroptera: Leptophlebiidae). Aust. J. Mar. Freshwat. Res. 32:121-131.

Balodi VP and Koshal Kumar (2015) MacroZoobenthic study in relation to physico Chemical parameters of Khoh River in Uttarakhand. Int. J. of Sci. Res. Vol.4 (6) 171-173.

Bishop JE and Hynes HBN (1969). Downstream drift of the invertebrate fauna in a stream ecosystem. Arch. Hydrobiol. 66:56-90.

Brittain JE and Eikeland TJ (1988) Invertebrate drift-a review. Hydrobiologia, 166(1): 77-93.

Casey RJ (1987) Diel periodicity in density of Ephemeroptera nymphs on stream substrata and the relationship with drift and selected abiotic factors. Can. J. Zool. 65: 2945-2952.

Ciborowski JJK (1983) Influence of current velocity, density and detritus on drift of two mayfly species (Ephemeroptera). Can. J. Zool 61: 119-125.

Dobriyal AK, Balodi VP, Joshi HK, Thapliyal A, Bahuguna P, Uniyal SP and Kotnala C B 2009. Substratum heterogeneity and indicator macro-zoobenthos of the Eastern Nayar, Garhwal, Central Himalaya. J. Mountain Res. 4: $130-135$

Elliott JM (1968) The daily activity patterns of mayfly nymphs (Ephemeroptera). J. Zool. 155: 201-221.

Elliott JM (2002) Time spent in the drift by downstream-dispersing invertebrates in a Lake District Stream. Freshw. Biol. 71: 112122.

Field and Dodgson MS (1985) A simple and efficientdriftsampler. New. Zeal. J. mar. Fresh. 19: 167- 172.

Graesse A and Lake PS (1984) Diel changes in the benthos of stones and of drift in a Southern
Australian upland stream. Hydrobiolo. 111:153-160.

Harker J E (1953). The diurnal rhythm of activity of mayfly nymphs. J. Ex. Biol. 30: 525-533.

Hay C H, Franti T G, Marx D B, Peters E J and Hesse L W (2008). Macroinvertebrate drift density in relation to abiotic factors in the Missouri River. Hydrobiologia 598: 175-189. Hughes N F (1998). A model of habitat selection by drift-feeding stream salmonids at different scales. Ecology, 79(1): 281-294.

Hynes HBN (1970) The Ecology of Running Waters. Liverpool Univ. Press, U.K., 555 pp.

Katoch PD, Balodi VP, Thapliyal A, Koshal Kumar, Md. Rashid, Md. Sagir and Dobriyal AK (2015) Population structure and diversity analysis of benthic Ephemeropterans in Western Nayar river during 2014-15, J. Mountain Res., 10: 55-66.

Koshal Kumar, Rana JS, Rana AR and Kotnala, CB (2017) Checklist of Benthic Macroinvertebrate Communities of Stream Rawasan In Garhwal Region (Central Himalaya), Uttarakhand (India). J. Mountain. Res 12: 91-95.

Kohler SL (1985) Identification of stream drift mechanisms: An experimental and observational approach. Ecology 66 (6): 1749-1761.

Moon HP (1940) An investigation of the movements of fresh-water invertebrate faunas. J. Anim. Ecol. 9: 76-83.

Muller K (1954) Investigations on the organic drift in north Swedish streams. Rep. Inst. Freshwat. Res. Drottningholm 35: 133-148.

Muller K (1974) Stream drift as a chronobiological phenomenon in running water ecosystems. Annu Rev Ecol Systemat 5: 309-323.

Needham I G and Needham P R (1962). A guide to the study of freshwater biology. San Francisco Holden Day Inc. 108 PP.

SmockL A (1996). Macroinvertebrate movements: Drift, colonization and emergence. In Hauer, F. R. and G. A. Lamberti(eds.), Methods in stream ecology, Academic Press, New York. 
Statzner B and Mogel R (1984) No relationship between the substrate surface densities and drift of the stream caddis fly Micrasema longulum (Brachycentridae: Trichoptera). Proceeding of the $4^{\text {th }}$ International Symposium on Trichoptera, Clemson, South Carolina, 1983. Edited by J. C. Morse. Dr.W. Junk by Publishers, The Hague: 383-389.

Statzner B, Elouard, JM and Dejoux C (1985) Field experiments on the relationship between drift and benthic densities of aquatic insects in tropical streams (Ivory Coast). II. Cheumatopsyche falcifera (Trichoptera: Hydropsychidae). J. Anim. Ecol. 55:93-110.

Tomka I and Zurwerra A (1985) Key to the genera of the Heptageniidae (Ephemroptera) of the Holarctic, Oriental and Ethiopian region. Em. Ber. Luzern. 14: 113- 126.

Townsend CR (1989) The patch dynamics concept of stream community ecology. J. N. Am. Benthol. Soc. 8(1): 36-50.

Ward HB and Whipple GV (1966) Freshwater Biology (ed. W.T. Edmondson). Wiley and sons. Inc. New York 1203 pp.

Waters TF (1972) The drift of stream insects. Annual Review Entomology 17: 253-272.

Wiley MJ and Kohler SL (1980) Positioning changes of mayflies nymphs due to behavioural regulation of oxygen consumption. Can. J. Zool. 58: 618-622.

Wiley MJ, and Kohler SL (1984) Behavioral adaptations of aquatic insects. In: The ecology of aquatic insects. Edited by V. H. Resh and D.M. Rosenberg. Frederich A. Praeger Inc., New York pp. 101-133.

Wilzbach MA (1990) Nonconcordance of drift and benthic activity in Baetis. Limnol. Oceanogr. 35(4): 945-952. 